\title{
Documenting Mexican Folk-art Linguistic Heritage: The Application of the Sets Theory to Determine its Common Terminology
}

\author{
Claudio Molina Salinas ${ }^{1}$ \\ Instituto de Investigaciones Estéticas \\ Universidad Nacional Autónoma de México
}

\begin{abstract}
This article shows the application of an ethnographical method (lexical availability method) and diverse strategies for lexical documentation (documentation of terminology in gray literature and other published documents) to the compilation and validation of the terminology of folk-art in Mexico, a knowledge area with scarcely written tradition. As one can foresee, the result obtained from the lexicon through the different methods and strategies of documentation applied allows registering several terminological lists. From these lists and by determining the intersection of two or more lexical sets, principle obtained from the set theory, one can obtain a group that contains the most frequent elements or the common terminology of a domain. In addition to the above, the article explains how a facets system for the basic organization of this terminology can be created from the lexical documentation obtained.
\end{abstract}

Keywords: cultural terminology, lexical documentation methods, ethnographical methods, folk art terminology, dictionary-making.

This paper is the result of a line of research on the lexicon in a permanent research seminar around art history and folk art at Instituto de Investigaciones Estéticas (IIE) of Universidad Nacional Autónoma de México (UNAM). ${ }^{2}$ The purpose of this seminar is the research on folk art in Mexico, the cataloging of a collection of folk art's works, kept by the University, which were exhibited in 1968 in the Cultural Olympiad of Mexico, and the elaboration of the Historical Glossary of terms related to Folk Art. ${ }^{3}$

The work related to the elaboration of the Glosario histórico de términos relacionados al arte popular aims to develop an innovative model of a historical-chronological glossary, its online publication, the creation of a model of historiographic definition, and the documentation and identification of terms of the domain. Regarding the latter, the scope of this article is to integrate the proposals and concerns of linguistics, librarianship, and terminology, and apply them to an area in which the absence of textual tradition predominates, proposing a methodology of ethnographic character that allows the construction of a terminological corpus from the recovery of predominantly empirical and oral knowledge. In this way, I want to address a subject that has not been approached from this perspective, although there is ample historical and ethnographic research.

\footnotetext{
${ }^{1}$ Corresponding Author E-Mail: claudio.molina.salinas@ comunidad.unam.mx.

2 PAPIIT Project IN400520: “Artesanías en transición 1950-1980”, whose head is Deborah Dorotinsky Alperstein, $\mathrm{PhD}$.

${ }^{3}$ Folk-art's works are not exclusive to Mexico. In the 1968 Olympics, which took place in Mexico, a cultural Olympiad was held, and one of its activities was the integration of a collection of folk-art's works from all the participating countries in the Olympics. The research group to which I belong works with this collection called "Muestra del arte mundial". If you are interested in knowing more about it, I will provide the following link: https://artsandculture.google.com/asset/\%E2\%80\%9Cmuestra-del-artemundial\%E2\%80\%9D/oQHQCvVx4tmGjw.
} 


\section{Why Document Folk-art Heritage Terminologies?}

The description and protection of cultural heritage have been mainly focused on objects, putting aside vital linguistic components linked to them, their names, and the meaning the concepts evoke within their social context. Due to this, it is possible to find cases of terminological variability in which a work is documented with different terms, or even where the names are unknown, as well as several cases in which the meaning related to a concept is ambiguous for the members of an area of knowledge.

To summarize, the tradition centered on the objects of the institutions of the Mexican cultural sector has focused on the descriptions of the work and their preservation conditions, and it has neglected the description of the linguistic component whose purpose is to denominate objects. To provide a theoretical explanation of the signification of these elements, Ullmann's semiotic triangle is presented (Ullmann, 1967, p. 67; Geeraerts, 2010, p. 279), in which the linguistic elements (denominative and significative) and their relationship with objects are represented.

\section{Figure 1}

Ullmann's triangle (Ullmann, 1967, p. 67), reconstruction of Ogden \& Richards' triangle

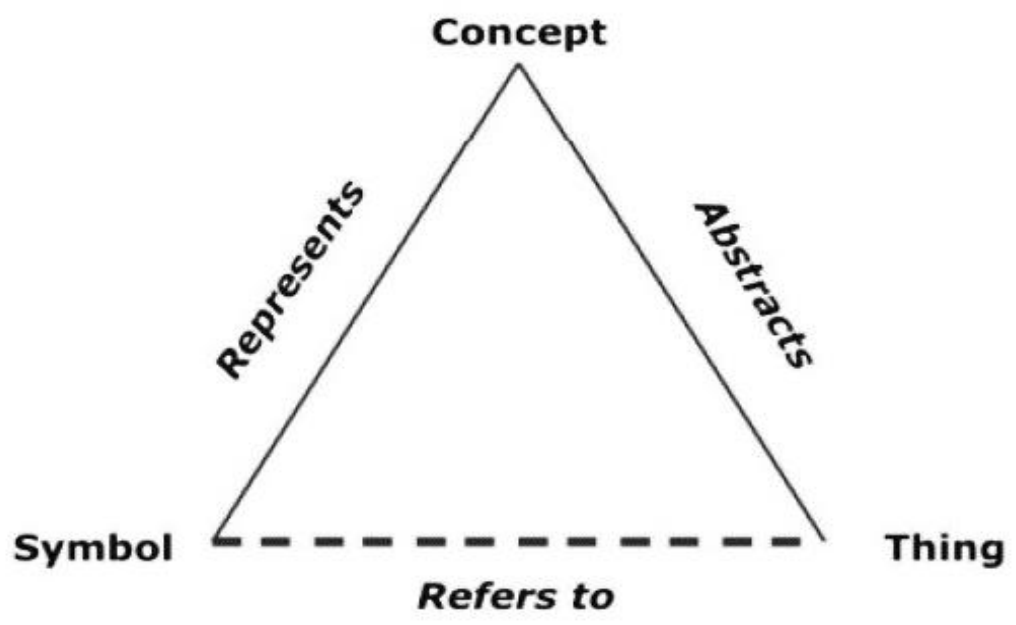

In this instance, "symbol" is the phonetic or orthographic component that represents a notion generally known as denomination or term (Cabré i Castellví, 1998; Lara Ramos, 2018). "Concept" refers to the information that communicates with "symbol"; it is also the meaning or notion (Cabré i Castellví, 1998; Lara Ramos, 2018); and finally, "thing" or the non-linguistic referent in question. In general, it is taken as read that these three elements cannot be conceptually separated, and that together form a single meaning unit or sign (Ullmann, 1967; Lara Ramos, 1997a; Geeraerts, 2010).

Taking into consideration the unavoidable relation between things and their denominations, as well as the fact that there are multiple international works on heritage, art, and architecture terminology (linguistic component), such as The Getty Vocabularies (The Getty Research Institute, n.d.) and their different translations to other languages, TesaurosDiccionarios del Patrimonio Cultural de España (Ministerio de Cultura y Deporte, n.d.), Iconclass (RKD Iconclass, 2012) or Tesauro de la UNESCO (UNESCO, n.d.), a method of terminological documentation is proposed in this article that allows focusing efforts on the 
documentation of terms of folk art in Mexico, and later to build controlled vocabularies related to the country's cultural sector.

\section{Written Texts Corpora and Terminology Control of Folk Art in Mexico}

The current approach and study of human knowledge have resulted in the creation of a research area where human disciplines, means, and digital tools converge (Combi, 2016) (also known as digital humanities).

Within the context of this research and the disciplines in charge of the study and control of vocabularies (corpus linguistics, terminology, and library science), working approaches that have taken into account the use of big textual sets have been developed, of which terminologies are extracted through methods that make use of mathematical and linguistic rules, as well as artificial intelligence (European Association for Digital Humanities, 2006). These methods of terminological extraction based on big linguistic corpora, allow for the management of a bigger number of empirical data and, in turn, the quantification of the frequency of terms that allow determining the preferred, alternative, and canceled terms, among others. Unfortunately, this approach has application issues in areas where an established textual tradition is lacking, such as folk art in Mexico. This renders the frequency estimation of lexical items virtually impossible with commonly used methods such as calculation of relative frequency (Muller, 1973), relative frequency per million (Biber et al., 1998; McGillivray et al., 2020), or corrected frequency, as reported in Ham (1979) or Bogaards et al. (2004) and, therefore, the determination of a common vocabulary for an area of knowledge.

As one can foresee, the folk-art domain in Mexico is an area of expertise with a mostly empirical knowledge inherited among generations of artisans and artists, and with a prescientific character. Therefore, there are not enough moderated publications and where there is an absence of a wide textual tradition that can help build a representative and balanced terminological corpus. Based on this, a method is proposed that takes into consideration the ethnological work in practice communities and the application of the set theory to determine the basic terminology of the area of knowledge, as well as the differentiated terminologies.

\section{An Opportunistic Selection of the Terminology of Folk Art in Gray Literature (Museum Labels)}

By the end of the 19th century, the Vocabulario de mexicanismos comparado con los de otros países Hispano-Americanos (Icazbalceta García, 1899) was published. In this document's prologue, a common problem that affects the coverage or effectiveness a dictionary has at the moment of recording the lexicon is discussed. Icazbalceta García (1899) points out that basing the documentation of a dictionary on published works by prestigious authors or "Authorities" is the right path for documenting the uses of the lexicon; however, he also suggests taking into consideration common uses that lie in regional and colloquial texts and spontaneous spoken manifestations to obtain a more representative lexicon compilation and description of languages.

Currently, in more recent works regarding Spanish such as the Diccionario del Español de México (Lara Ramos, 2010), a corpus which serves as documentation of the dictionary compiles both literary works and periodical publications of science and techniques, as well as recorded conversations, popular literature, and regional and occasional documents (Lara Ramos \& Ham Chande, 1974).

Therefore, considering this methodology for documenting lexicon (widely accepted in Hispanic tradition, to say the least) and taking into consideration the poor documental availability the domain has, a first step proposed for the documentation of the lexicon of folk 
art in Mexico is to recover the terminology of the domain from the museum labels and exhibitions presenting works of folk art. This first step corresponds to a type of convenience or purposive sampling (Casal \& Mateu, 2003) where we gathered the lexicon registered in the exhibition labels of folk art. Even though this course of action does not statistically represent the domain's reality, as shown later, the following steps of the proposed method compensate for the overrepresentation or underrepresentation of this type of sampling.

The course of action in this step was as follows: art historians, linguists and other specialists involved attended different folk-art exhibitions regularly during 2019 and the beginning of 2020. All of them are or were presented in 10 museums of Mexico that exhibit or exhibited folk-art collections. These institutions were: the Museo Regional de Cholula, the Museo Carrillo GIL, the Museo del Centro Cultural "Los Pinos", the Museo de Arte Popular de la Ciudad de México, the Museo Universitario de Arte Popular de Colima, the Museo del Palacio de Valparaíso, the Museo del Palacio de Iturbide, the Museo Nacional de Culturas Populares, the Museo Nacional de Antropología (ethnography section) and the Museo de la Máscara de la Peña de Bernal.

The labels for these museums are like the case represented in Figure 2 in the arrangement of their work's information. This example was photographed at the Museo de Arte Popular de la Ciudad de México:

Figure 2

Museum label of folk art in Mexico City

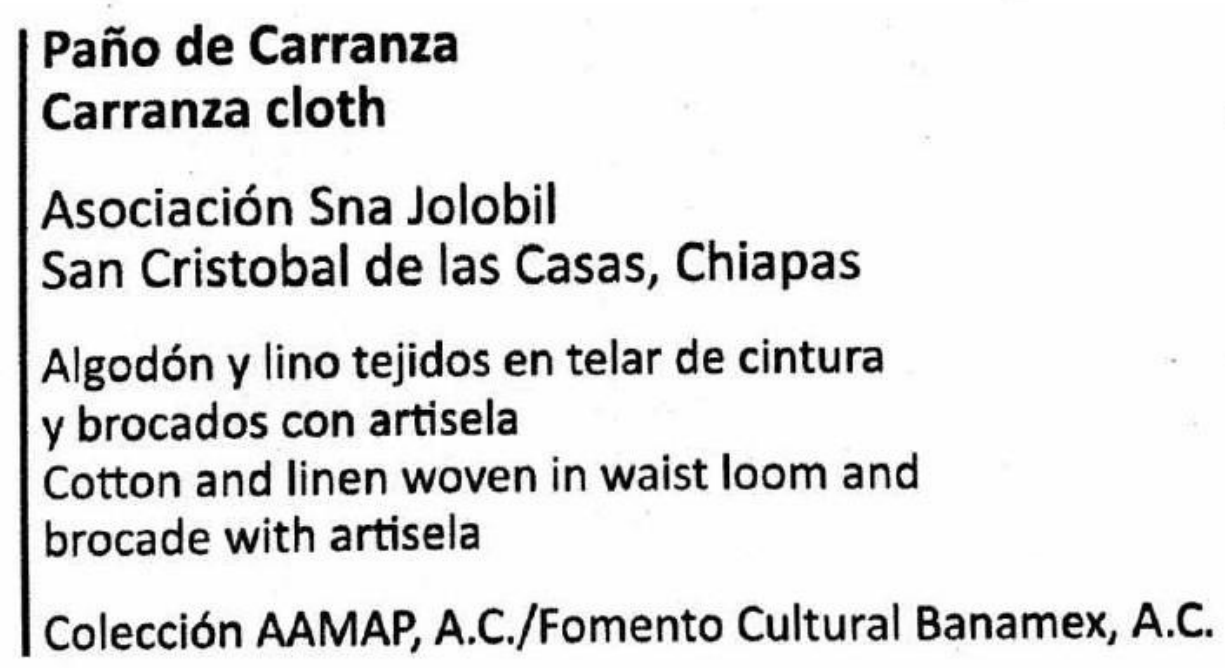

As can be seen in Figure 2 (bilingual label), information related to the type of object is presented, such as (paño de Carranza/Carranza cloth), the agent or institution producer of such work, Asociación Sna Jolobi), the work's place of origin (San Cristóbal de las Casas, Chiapas), the materials and techniques involved in its manufacturing (algodón y lino tejidos en telar de cintura y brocados con artisela/cotton and linen woven in waist loom and brocade with artisela) and the agents owner of the object (Colección AAMAP, A.C/Fomento Cultural Banamex, A.C.).

The example in Figure 2 represents a challenge for identifying the terminology since some information elements in museum labels, such as materials and techniques involved in the works manufacturing are presented in a single field, and due to a matter of reading style of the labels, the terms are within a single phrase, and not as a list. 
Therefore, to identify the terms, we address two criteria. First, linguistic criteria as a way in which the terms designate or refer to concepts (Cabré i Castellví, 1998; Lara Ramos, 2006) and the implementation of tests related to the composition of the Spanish lexicon ${ }^{4}$ (Alonso Ramos, 2010); and secondly, the linguistic competence of the documentalists involved in the task.

The linguistic tests applied to identify the terms of the domain are expressed grosso modo below, and they are illustrated with examples taken from the label in Figure 2.

- From the point of view of how the term refers to the thing:

- All terms are lexical units that designate an object, concept, or process of a knowledge area (Cabré i Castellví, 1998). Therefore, we consider as a term every monolexical or multilexical unit that designates a reality. In this sense, algodón "cotton" and telar de cintura "waist loom" are terms, because they refer to the material and an object.

- The lexical units of Spanish usually have idiomatic or componential meanings (Alonso Ramos, 2012); i. e., in some cases their meanings can be recovered from the elements that form the term, such as in telar de cintura "waist loom" - 'a loom which holds to the weaver's waist'- or idiomatic cases, in which the lexical meaning cannot be inferred from the elements that form the term. In the case of paño de Carranza "Carranza cloth", the surname does not make a direct reference to the type of object. In this example, the documentalist must be careful given that in some cases of compositional meaning, they could be phrases and not lexical units. For this, the interaction with the following tests regarding the conformation of the lexicon becomes crucial.

- From the point of view of the tests related to the conformation of the lexicon:

- For the case of complex terms (multilexical), it is important to consider the positioning of the term and the loss of referentiality as a criterion to recognize lexical units (Alonso Ramos, 2012). In this case, by changing the order of telar de cintura "waist loom" or paño de Carranza "Carranza cloth" for * cintura de telar or *Carranza de paño, there is a loss of referentiality and grammaticality of the term. Therefore, one needs to consider telar de cintura and paño de Carranza as terms.

- Another common test is to replace, remove, or add lexical elements to the term (Alonso Ramos, 2012). If such tests do not substantially alter the meaning, they are not terms, but phrases. In the case of telar de cintura "waist loom" or paño de Carranza "Carranza cloth", any of the three procedures results in the loss of referentiality.

- Lastly, it is important to consider that for a complex lexical unit (multilexical) to be considered a term, it must be morphologically fixed to it. Therefore, certain changes in number and gender would not be accepted in its components for Spanish (Alonso Ramos, 2012). Moving back to the previous example, it would be irregular to say telar de cinturas or telares de cinturas, given that the plural must solely affect the head of the compound: telares de cinturas.

From this documentation process through the museum labels, the documentalists classified and arranged the terms in lists corresponding to each one of the information elements present in the labels, regardless of them being highlighted with a title or not or differentiated as

\footnotetext{
${ }^{4}$ In this case study, formation rules for words in Spanish and tests for identifying our lexicon are considered, given that the terminology intended to be documented is for this language. Naturally, in cases relative to other languages, their own lexical unit's identification tests must be carried out.
} 
a type or mixing various terminological categories. This is shown in the example of Figure 3 , an example photographed at the Museo Regional de Cholula.

\section{Figure 3}

Label for a vat. Museo Regional de Cholula

Tinaja
Barro bruñido
Tehuiltzingo, S XX

From this label, three candidate terms were documented: tinaja "vat", barro "mud", and bruñido "burnishing"; a geographic name: "Tehuiltzingo"; and a timespan: $S X X$ "twenty century". This step started shaping a faceted system for the terms with this arrangement:

\section{Figure 4}

A first approach to the facets of the Mexican folk art's terminology

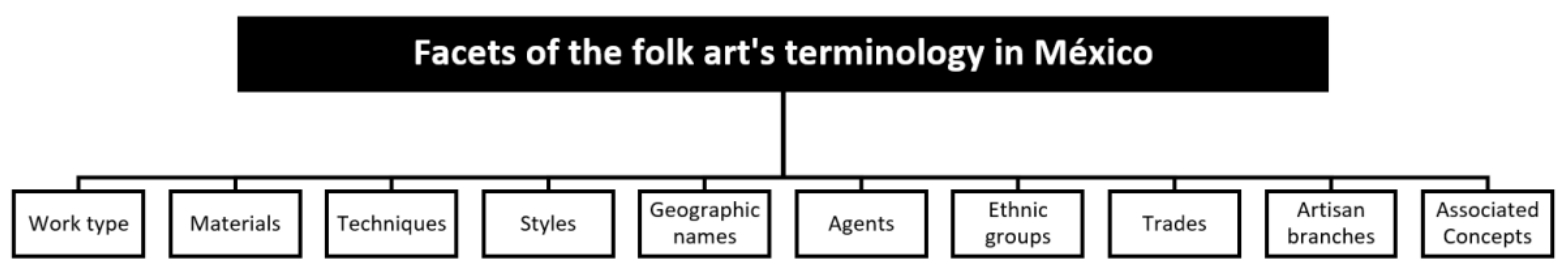

This first step allowed me to document 4330 candidate terms spread across the proposed facets as follows: work type (945), materials (1038), techniques (437), styles (25), geographic names (1336), agents (424), ethnic groups (9), trades (4), artisan branches (36), and associated concepts (76). All these terms were gathered in each terminological list.

Finally, two types of rules were applied to the transcription of the terms present in these terminological lists: first, the orthographic rules proposed for Spanish by the Real Academia Española y Asociación de Academias de la Lengua (2010) and the lemmatization rules that would allow us to identify the term representing all its inflectional forms (Lara Ramos, 1997b).

The orthographical rules applied to the terms are focused on the correct use of uppercase letters, Spanish accent marks, and the correct use of special orthographic characters. For example, we found cases such as *Polvora, *Mascara, Arte "bajo" and Ex-voto, whose uppercase letters were replaced, the corresponding accent marks were incorporated and the special characters were removed: pólvora, máscara, arte bajo, and exvoto. ${ }^{5}$ In cases where many orthographic possibilities are available, the terms' orthography was not modified, such as in cempasúchil, sempasúchil y zempasúchil.

The applied lemmatization rules imply switching forms that were documented in the plural to singular, such as in nacimientos or candelabros, for nacimiento and candelabro, although cases in Spanish that are always conceptually conceived as plurals remained

\footnotetext{
${ }^{5}$ The application of these rules is indicated in bold to understand the changes.
} 
unchanged: aretes o cubiertos. Lastly, all terms in female gender were switched to male, as in tejida, bordada, and pintada, for tejido, bordado, and pintado.

\section{The Application of the Lexical Availability Method for Documenting Terms of Folk Art in Primary Documentation Sources}

The available lexicon is a potential set of lexical units that are part of the mental lexicon of a speaker. This set is cognitively arranged from various themes, also known as centre d'intérêt (Lara Ramos, 2006; López Morales, 1995). From this concept, in the mid-20th century in France and other European countries, various methods of lexical availability were developed. Grosso modo, the lexical units allocated in the mental lexicon of an informant were retrieved from the presence of some stimulus or question made to them (Gougenheim et al., 1956).

Some applications of the lexical availability method have been focused on determining the fundamental lexicon of a particular language (López Morales, 1995), detecting the main shortcomings of vocabulary in students of pre-university or middle-level schools (López Chávez, 2003), knowing the variety in the general lexicon present in different dialectal areas of Spain and Hispanic America (Bartol Hernández, 2006), and more recently, gathering the terminology of an area of knowledge through the application of a questionnaire (Molina Salinas et al., 2018).

This adaptation of the lexical availability methodology for documenting terms involves the application of a presential questionnaire to a group of informants, specialized in domain knowledge. The list or lists of lexical units obtained are open since the surveyed informants have the freedom to write all possible lexical items that they relate to the themes (Molina Salinas et al., 2018).

In this case, I seized the seminar reunion of the PAPIIT IN400520 project "Artesanías en transición" of the Universidad Nacional Autónoma de México's Instituto de Investigaciones Estéticas, where seventeen specialists of folk art (historians, art historians, anthropologists, museologists involved in the topic, and students of history and Latin American studies majors), answered a lexical-terminological availability questionnaire I developed ad hoc. This questionnaire has six questions related to six topics or centre d'intérêt.

It is also important to point out that such questionnaires recorded variables related to the informant, such as age, gender, academic background, professional formation, and nationality, to keep a record and take into consideration the terminological variety when including the results. The full questionnaire can be checked at the end of this article, in "ANNEX I. Cuestionario de disponibilidad léxica aplicado a especialistas".

Regarding the questions, they were defined and adapted from the faceting proposal of the terminological documentation in the museum labels (Figure 4). Although this initial proposal is comprised of ten facets: work type, materials, techniques, styles, geographic names, agents, ethnic groups, trades, artisan branches, and associated concepts, I included three facets in one: first, because there were cases such ethnic groups and trades, which only registered nine and four terms each, and having only one category for a handful of elements is impractical. Secondly, because facets such as artisan branches, ethnic groups, and trades could be conceptually included in a wider facet such as associated concepts.

Finally, agents were not taken into consideration given that they are a facet that connects a lot of information, and due to the time limit of three minutes indicated for each answer. Because of this, the application of a second questionnaire was taken into consideration ${ }^{6}$. By making this decision, our facets system was reconsidered and adopted this shape, in which the

\footnotetext{
${ }^{6}$ Unfortunately, given that the method implies the presential application of the questionnaire to a large group, and due to the 2020 pandemic preventing us from continuing with this work, the documentation of the names of the agents is a research line we will address as soon as possible.
} 
themes artisan branches, ethnic groups, and trades become subordinates under the associated concepts category.

\section{Figure 5}

A second approach to the facets of folk-art terminology in Mexico

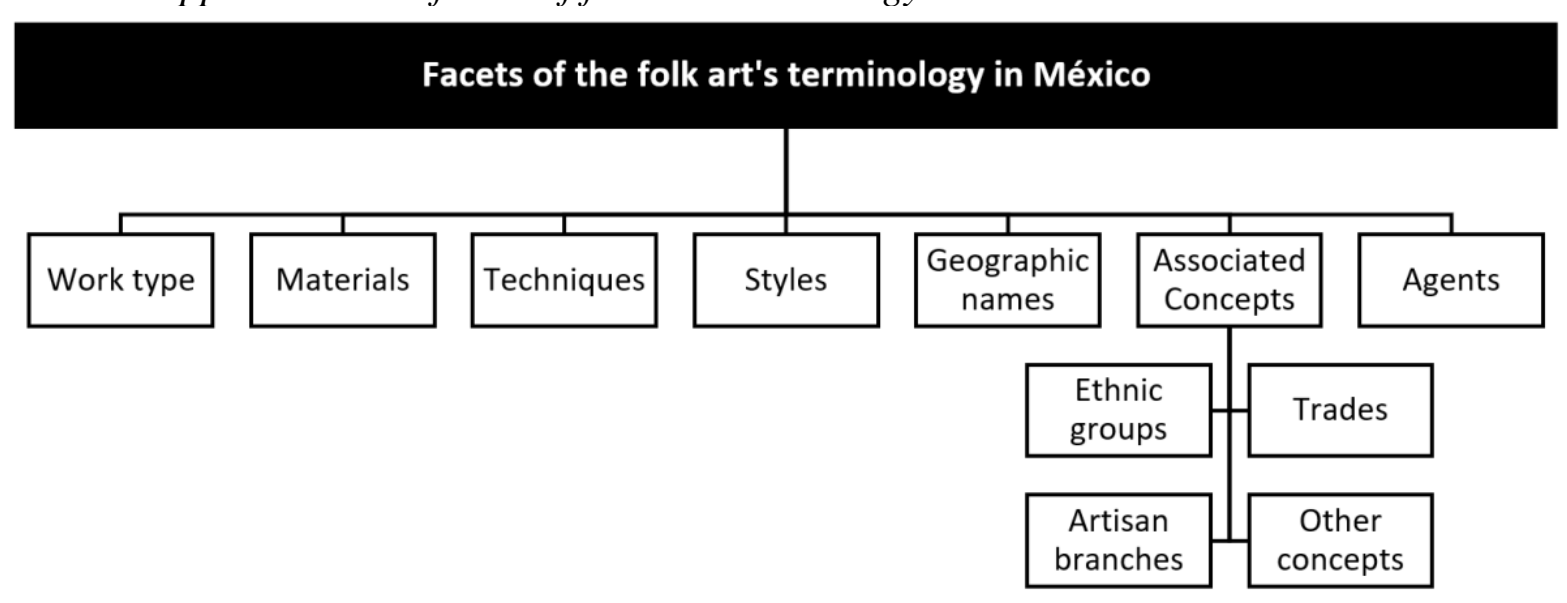

Considering a future need to systematize the folk-art terminology in facets that correspond to the way of cataloging using international metadata standards, a revision of the information elements considered in standards for the cataloging of heritage objects was carried out.

From this revision, it can be concluded that there are at least three widely-used and known standards in the recording, study, and preservation area of cultural objects that would be compatible with the organization of our terminology in these facets: Object ID (Thames et al., 1999), VRA Core 4 (Visual Resources Association, 2007), and CIDOC CRM (Aalberg et al., 2018), given that they take into account information elements that require concepts such as work type, materials, techniques, styles, geographic names, and agents. Additionally, one can say that this faceting reconsideration is also consistent with vocabularies such as The Getty Vocabularies (The Getty Research Institute, n.d.), as well as the Tesauros-diccionarios del patrimonio cultural de España.

By processing the results of the seventeen questionnaires, rules were applied that corresponded to how Spanish lexical units are treated, before their inclusion in a reference work. These orthographic and lemmatization rules have already been explained in the previous section.

Finally, the results obtained in this step are the following: in total, we documented 1311 of which 349 are work type, 295 materials, 186 techniques, 88 styles, 210 geographic names or regions where folk art is present, and 183 associated concepts. Each one of them is recorded in the terminological lists. ${ }^{7}$

\section{Validation of the Terminology and Estimation of Common and Differential Terms of Folk Art}

In this last step proposed for the validation of common and differential terminologies of folk art, two procedures have been implemented: the first one is the integration of a textual corpus of available documents of the area; the second one is the comparison of the two sets of terminological lists obtained with the sources of documentation of the corpus, and the determination of the common and differential terminologies.

\footnotetext{
${ }^{7}$ The full terminology list can be checked at the end of this article, in "ANNEX II. Listado terminológico".
} 
As mentioned before, the available textual documentation on the area of folk art in Mexico is scarce. For example, the searches in the catalog of the "Biblioteca "Justino Fernández" " 8 only records a total of 272 documents under the theme "folk-art": less than $0.5 \%$ of all the works of the library. If this data is already of concern, it is relevant to consider that this figure is even lower for the case of the description of folk art in Mexico since the documentation regarding Mexico is comprised of only 116 documents (around $0.2 \%$ of the whole collection).

In virtue of this, during the last two years, a proposal to work in a seminar has been put forward: the seminar "Artesanías en transición" whose objective is to share, concentrate and discuss several theoretical lectures on folk art in Mexico. The revision process and bibliographic discussion of the seminar have allowed us to concentrate and review 118 texts of folk art (ninety documents in Spanish and twenty in English and French), that do not strictly match the ones present at the "Biblioteca 'Justino Fernández"' but that have the features of academic rigor and relevance the seminar requires. All these documents were organized in the Mendeley bibliographic reference manager ${ }^{9}$ given that this tool allows for the bibliography to be organized, kept online to be used by the working group, and perform advanced searches by author, title, publication, year, and notes.

After finishing the terminological documentation work in the museums and the application of the terminological availability questionnaire with specialists in the area, six lists of candidate terms with more than five thousand lexical items could be incorporated ${ }^{10}$. However, to provide a guarantee that that the candidate terms were terminological units of the domain, a procedure of validation of the terms in the documentation of our corpus was implemented. For this, the "Authority" principle from library science has been considered, where it is expected that different information sources can provide a guarantee about a terminology, let it be a specialist, a practice community, or an institution (Barité, 2009).

Naturally, the obtention steps of terms in museums and with specialists could guarantee the use of terms in folk-art in Mexico. However, the idea about documentation errors or errors related to the information given by the informants has been taken into consideration. For example, I have noticed that a specialist reported that "s. XVIII" is an associated concept, while the museum labels and the rest of the specialists indicated it is a time span. Assuming this type of human errors is natural and more common than expected, a proposed solution is based on the obtention procedure of the "common lexicon" of a practice community, an approach based on the set theory.

To determine the "common lexicon" of a practice community, a speaker's knowledge about his lexicon is considered and contrasted with other community members. The lexical items common to all members of this practice community constitute the "common lexicon" (Lara Ramos, 2006). A graphic explanation of this can be seen below:

\footnotetext{
${ }^{8}$ Biblioteca del Instituto de Investigaciones Estéticas de la Universidad Nacional Autónoma de México, regarded as the most important documental collection in Mexico regarding fine arts, which has more than 55000 specialized works. The library's website and its catalog can be found on the following address: http://www.esteticas.unam.mx/biblioteca.

${ }^{9}$ This decision is justified since our university offers $100 \mathrm{~GB}$ of storage for each collaborator.

${ }^{10}$ As explained before, at this stage only 5 lists will be worked on (work type, materials, techniques, styles, geographic names, and associated concepts), leaving the list of agents for other stages of the research.
} 


\section{Figure 6}

The intersection of the individual lexicon of four speakers or the "common lexicon" (Lara Ramos, 2006, p. 152)
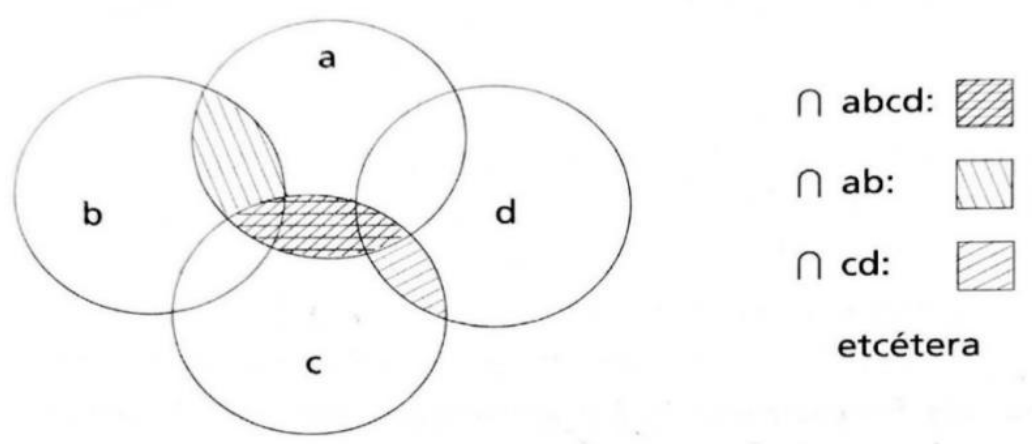

In Figure 6, sets a, b, c, and d, represent the common lexicon of four informants and the intersection of $\mathrm{a}, \mathrm{b}, \mathrm{c}$, and $\mathrm{d}$ (" $\cap$ abcd") represents the "common lexicon" of these informants. Taking into account the above, as well as the possible terminological documentation errors presented, a validation of the terminological lists by crossing information in the same way illustrated in Figure 6 has been put forward in a way that, if a term is registered both in the lists of available terms, and in the museum labels and corpus documents, this set of terms could be considered a type of "common lexicon" or, more precisely, the common terminology of folk art.

To summarize, the efforts to validate and determine the common terminology of the domain, considering our data, is comprised of three steps: first, we start from the lists of terms obtained in the museums; secondly, we corroborate that the terms were recorded in the lists of candidate terms obtained through the lexical availability method. Finally, we looked for the terms in the documents of the corpus. In this way, we could validate and identify the common terminology of folk art in Mexico, assuming each source of terminological information works as a different type of "Authority." The result of this information crossing can be graphically represented as follows:

\section{Figure 7}

Representation of the intersection of the terminology labels, the available terminology among specialists, and the terminology in the corpus

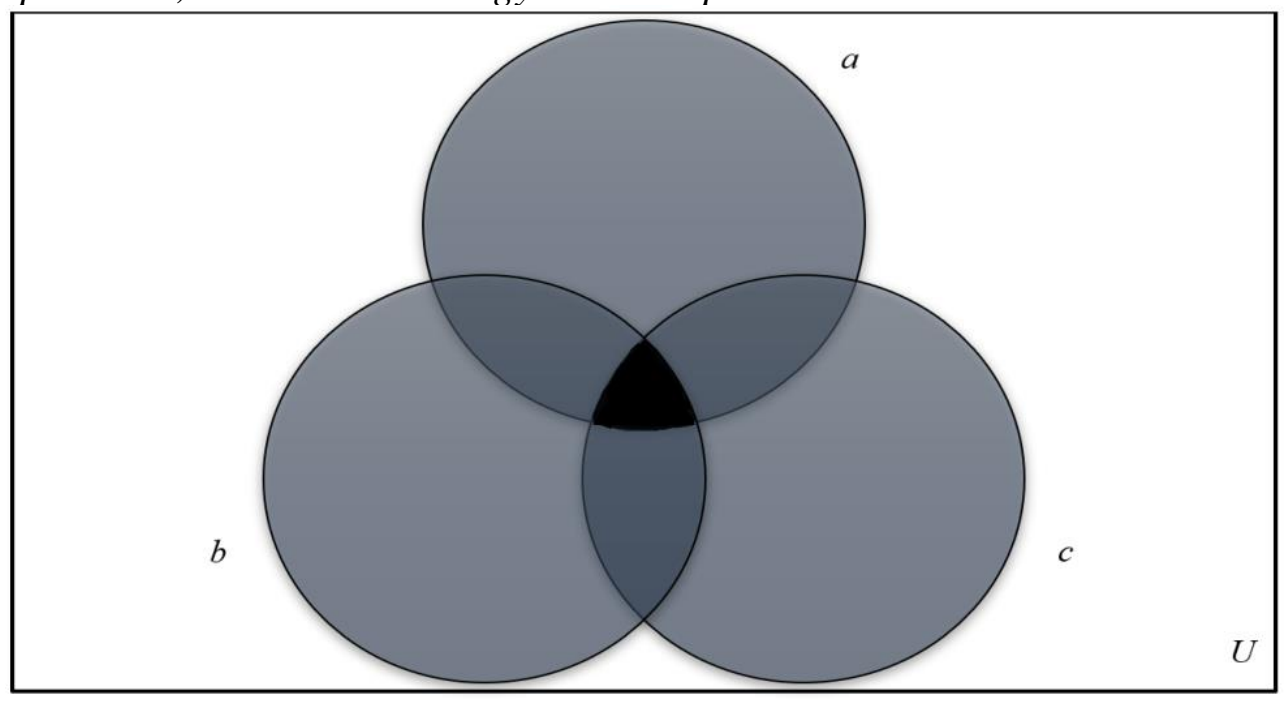


Where the intersection of the terminology documented in labels (set a), the available terminology (set b), and the terminology documented in the corpus (set c) can be seen in black (" $\cap a b c ")$ and represents the common terminology of the domain. Three additional sets where sets $a$ and $b$ ("a $\cap$ b"), $b$ and $c$ ("b $\cap c$ "), and a and c ("a $\cap c$ ") intersect can be seen which, in this case, represent the differential terminologies used in museums and by specialists, specialists and in documents, and in museums and by specialists. These sets would be a more specialized selection of the terminology, while the intersection of the three sets (" $\cap$ abc") would be the most common.

An objection that could be set forward to this analysis is related to the set differences: "a $\backslash b c$," "b \ac," and "c $\backslash a b$ " which are not considered in the analysis and were excluded from the verified terminology, although, in the end, they collect terms. The fact is that these subsets, by being unable to be validated against another "Authority," should not be included as terms of the domain, given that there is a risk to validate a one-time occurrence or hapax legomenon. However, this does not discard that these terms could be documented and validated in the future.

\section{Conclusions}

This article has presented the case study of folk art in Mexico and the way its common and differentiated terminologies are determined, as well as the steps to shape the facets that organize them. The method consists of six steps that are presented below for those interested in carrying it out, and replicate the procedure:

It is necessary to select the terminological sources that serve as a documental basis. There must be at least two, with no limit to the amount.

- Regarding the case of gray literature sources like in this case, museum labels or other types of informal informational sources ${ }^{11} 7$, the realization of an opportunistic selection of the terminology will be considered, manually identifying the terms, and applying them in the transcription of these orthographic and lemmatization rules.

- Regarding the primary sources of documentation, that is, the informants, a questionnaire must be applied to obtain the available terminology.

- For all the previous cases, the terms must be organized in lists.

- A facets system of the domain could be built, was it to be the case, based on the findings made by carrying out the terminological work. This faceted system can and must be corroborated, comparing it to other existing initiatives such as ontologies, sources of reference, statements of specialized organizations in the area, among others.

- Finally, the intersection of the sets must be performed or corroborate which terms of a list appear in the rest of the lists or the terms that appear exclusively in others. This allows the analyzer to have a better idea about the more common terms, and about the ones which are for a specific use, depending on the kind of sources.

As explained before, this method removes the problem of overrepresentation of terms, in the case of the intersection of all the sets, given that by crossing the terminological information with other sources', errors coming from the information sources and the hapax legomenon are removed. Regarding the intersection between two sets, this is an alternative to

\footnotetext{
${ }^{11}$ In this case, fieldwork with artisans and artists of folk-art was also taken into consideration; however, the social and sanitary conditions of 2020 have prevented us from doing it, which does not mean that, as soon as these conditions change, such fieldwork can be carried out.
} 
validate the terminology and to compensate overrepresentation of terms. Lastly, the problem with the method is that it does not validate terms that could be useful for the domain. However, the proposed alternative is to establish a constant program of terminological documentation, something that, in my opinion, is desirable in every knowledge area.

The approach, insofar as it proposes an ethnographic methodology (lexical recovery in museums, documentary corpus, and interviews), implies a reflection on the historical construction of a cultural phenomenon: folk art, but not exclusively circumscribed to this domain. This method can be replicated in practically any area of knowledge that has a museum, gray literature, and documentation (biology, physics, anthropology, history, art, human rights...).

Studies derived from this method would be relevant for the study of cases of terminological variability, ambiguities, or absences, that is, the dynamic historicity of the significance of objects and, therefore, of the knowledge systems generated around them.

Finally, I would like to point out that the instruments generated from this proposal (vocabularies) are vital as new sources for the historical and ethnographic analysis of folk-art, understood as a social-historical phenomenon.

\section{References}

Aalberg, T., Balzer, D., Bekiari, C., Boudouri, L., Crofts, N., Eide, Ø., Gill, T., Goerz, G., Hagedorn, M., Hiebel, G., Inkari, J., Iorizzo, D., Kotipelto, J., Krause, S., Lampe, K. H., Lindenthal, J., Nyman, M., Riva, P., Rold, L., ... Žumer, M. (2018). Definition of the CIDOC Conceptual Reference Model. Version 6.2.3. ICOM/CIDOC CRM Special Interest Group.

Alonso Ramos, M. (2012). Sobre por qué un grupo de palabras puede ser una sola palabra sin ser paradójico. In E. T. Montoro del Arco (Ed.), Neología y creatividad lingüística (pp. 115-136). Universitat de Valencia.

Barité Roqueta, M. G. (2009). Garantía literaria y normas para construcción de vocabularios controlados: aspectos epistemológicos y metodológicos. Scire, 15(2), 13-24. http://www.ibersid.eu/ojs/index.php/scire/article/viewFile/3709/3470.

Bartol Hernández, J. A. (2006). La disponibilidad léxica. Revista Española de Lingüística (RSEL), 36, 379-396. https://doi.org/ISSN: 2010-1874.

Biber, D., Conrad, S., \& Reppen, R. (1998). Corpus Linguistics. Cambridge University Press. https://doi.org/10.1017/CBO9780511804489.

Bogaards, P., \& Laufer-Dvorkin, B. (2004). Vocabulary in a second language: Selection, acquisition, and testing. John Benjamins Publishing Company.

Cabré i Castellví, M. T. (1998). Terminology. Theory, Methods, and Application (J. C. Sager (ed.)). John Benjamins Publishing Company.

Casal, J., \& Mateu, E. (2003). Tipos de Muestreo. Revista de Epidemiología y Medicina Preventiva, 1, 3-7.

Combi, M. (2016). Culture and Technology: An Analysis of Some of the changes in Progress Digital, Global and Local Culture. In K. J. Borowieki, N. Forbes, \& A. Fresa (Eds.), Cultural Heritage in a Changing World (pp. 3-16). Springer Open.

European Association for Digital Humanities. (2006). Linguistics. The European Association for Digital Humanities Web Page. https://eadh.org/linguistics.

Geeraerts, D. (2010). Theories of Lexical Semantics. Oxford University Press.

Gougenheim, G., Michea, R., Rivenc, P., \& Sauvageo, A. (1956). L'élaboration du français élémentaire: étude sur l'établissement d'un vocabulaire et d'une grammaire de base. Didier. 
Ham Chande, R. (1979). Del 1 al 100 en lexicografía. In L. F. Lara Ramos, R. Ham Chande, \& M. I. García Hidalgo (Eds.), Investigaciones lingüísticas en lexicografía (pp. 43-83). El Colegio de México.

Icazbalceta García, J. (1899). Vocabulario de mexicanismos comparado con los de otros países hispano-americanos. La Europea.

Lara Ramos, L. F. (1997a). Por una nueva teoría del signo. In R. Barriga Villanueva \& P. Martín Butragueño (Eds.), Varia lingüística y literaria. 50 años del CELL, Vol. I (pp. 211222). El Colegio de México. https://doi.org/10.2307/j.ctv47w42s.17.

Lara Ramos, L. F. (1997b). Teoría del diccionario monolingüe. El Colegio de México.

Lara Ramos, L. F. (2006). Curso de lexicología. El Colegio de México.

Lara Ramos, L. F. (2018). Concepts and Term Hierarchy. Terminology, 5(1), 59-76.

Lara Ramos, L. F. (Ed.). (2010). Diccionario del Español de México (tomos I y II). El Colegio de México.

Lara Ramos, L. F., \& Ham Chande, R. (1974). Base estadística del Diccionario del Español de México. Nueva Revista de Filología Hispánica, XXIII (2), 245-267.

López Chávez, J. (2003). ¿Qué te viene a la memoria? La disponibilidad léxica: Teoría métodos y aplicaciones. Universidad Autónoma de Zacatecas/Unidad Académica de Letras.

López Morales, H. (1995). Los estudios de disponibilidad léxica: Pasado y presente. Boletín de Filología, 35(1), 245-259. https://core.ac.uk/download/pdf/46545239.pdf.

McGillivray, B., \& Tóth, G. M. (2020). Applying Language Technology in Humanities Research: Design, Application, and the Underlying Logic. Springer International Publishing.

Ministerio de Cultura y Deporte. (n.d.). Tesauros-Diccionarios del patrimonio cultural de España-Acceso a los tesauros. http://tesauros.mecd.es/tesauros/tesauros.

Molina Salinas, C., \& Franco Trujillo, E. D. (2018). Una metodología para la construcción de un sistema conceptual para un tesauro de las artes espaciales en México. Terminàlia, 18, 25-36. http://revistes.iec.cat/index.php/Terminalia/article/viewArticle/144213.

Muller, C. (1973). Estadística linguística. Gredos.

Real Academia Española y Asociación de Academias de la Lengua Española. (2010). Ortografía de la lengua española. Espasa-Calpe.

RKD Iconclass. (2012). Iconclass. http://www.iconclass.org/help/outline.

Thames, R., Dorrell, R., \& Lie, H. (1999). Introduction to Object ID. Guidelines for Making Records that Describe Art, Antiques, and Antiquities. Getty Information Institute.

The Getty Research Institute. (n.d.). The Art \& Architecture Thesaurus (Getty Research Institute). http://www.getty.edu/research/tools/vocabularies/aat/.

Ullmann, S. (1967). Semántica. Introducción a la ciencia del significado. Aguilar.

UNESCO. (n.d.). Tesauro le la UNESCO. http://vocabularies.unesco.org/browser/thesaurus/es/\#: :text=El\%20Tesauro\%20de\%2 0la\%20UNESCO,y\%20humanas\%2C\%20comunicaci\%C3\%B3n\%20e\%20informaci $\% \mathrm{C} 3 \% \mathrm{~B} 3 \mathrm{n}$.

Visual Resources Association. (2007). VRA Core 4.0 Element Description. https://www.loc.gov/standards/vracore/VRA_Core4_Element_Description.pdf. 


\section{Notes on Contributor}

Claudio Molina Salinas is majored in Hispanic language and literatures, Master of Hispanic linguistics, and $\mathrm{PhD}$ in linguistics by Universidad Nacional Autónoma de México. His preferred research lines are related to the study and description of heritage terminologies, specialized lexicography (terminography) and documentary languages. Currently, he is a researcher at Instituto de Investigaciones Estéticas of the Universidad Nacional Autónoma de México. Orcid: 0000-0001-5607-9924 


\section{ANNEX I. CUESTIONARIO DE DISPONIBILIDAD LÉXICA APLICADO A ESPECIALISTAS}

Disponibilidad terminológica en el dominio del "Arte popular"

Nombre:

Sexo:

Formación profesional e intereses:
Edad:

Nivel educativo:

Nacionalidad:

a. Enuncie todos los TIPOS DE OBJETOS relacionados con el "Arte popular" que le vengan a la memoria (tiene tres minutos para ello):

b. Enuncie todos los MATERIALES relacionados con estos tipos de objetos y con el "Arte popular" que le vengan a la memoria (tiene tres minutos para ello):

c. Enuncie todas las TÉCNICAS relacionadas con el "Arte popular" que le vengan a la memoria (tiene tres minutos para ello):

d. Enuncie todos los ESTILOS relacionados el "Arte popular" que le vengan a la memoria (tiene tres minutos para ello):

e. Enuncie todas las REGIONES en las que el "Arte popular" tiene presencia y que le vengan a la memoria (tiene tres minutos para ello):

f. Enuncie todos los CONCEPTOS ASOCIADOS (ramas artesanales, grupos étnicos, oficios, conceptos más generales, conceptos particulares, ideas afines) que se vinculan con la noción: "Arte popular" y que pueda recordar (tiene tres minutos para ello): 
ANNEX II. LISTADO TERMINOLÓGICO

\begin{tabular}{|c|c|}
\hline acero & material \\
\hline acetato & material \\
\hline acrilán & material \\
\hline acrílico & material \\
\hline acrílico & technique \\
\hline actividad económica complementaria & associated concept \\
\hline acuarela & technique \\
\hline adorno & work type \\
\hline aglutinante & material \\
\hline agua & material \\
\hline Aguascalientes & geographic name \\
\hline aguja & material \\
\hline aje & material \\
\hline alebrije & work type \\
\hline alfarería & work type \\
\hline alfombra & work type \\
\hline algodón & material \\
\hline alhaja & work type \\
\hline alimento & material \\
\hline alisado & style \\
\hline alisado & technique \\
\hline alpaca & material \\
\hline alta gama & associated concept \\
\hline alta temperatura & work type \\
\hline altiplano & style \\
\hline Altiplano & geographic name \\
\hline Altos & geographic name \\
\hline amate & material \\
\hline Amazonas & geographic name \\
\hline América & geographic name \\
\hline Amuzgo & geographic name \\
\hline ancestralidad & associated concept \\
\hline Andino & geographic name \\
\hline añil & material \\
\hline árbol de la vida & work type \\
\hline arcilla & material \\
\hline $\operatorname{arco}$ & work type \\
\hline arena & material \\
\hline arete & work type \\
\hline aretes & work type \\
\hline arte & associated concept \\
\hline arte & associated concept \\
\hline arte aborigen & associated concept \\
\hline arte aplicado & associated concept \\
\hline arte bajo & associated concept \\
\hline
\end{tabular}




\begin{tabular}{|c|c|}
\hline arte campesino & associated concept \\
\hline arte culto & associated concept \\
\hline arte culto & associated concept \\
\hline arte decorativo & associated concept \\
\hline arte del pueblo & associated concept \\
\hline arte del pueblo & associated concept \\
\hline arte elitista & associated concept \\
\hline arte folclórico & associated concept \\
\hline arte hecho a mano & associated concept \\
\hline arte indígena & associated concept \\
\hline arte industrial & associated concept \\
\hline arte ingenuo & associated concept \\
\hline arte manual & associated concept \\
\hline arte mecánico & associated concept \\
\hline arte menor & associated concept \\
\hline arte mexicano & associated concept \\
\hline arte nacional & associated concept \\
\hline arte naif & associated concept \\
\hline arte no industrial & associated concept \\
\hline arte popular campesino & style \\
\hline arte popular elitista & style \\
\hline arte popular indígena & style \\
\hline arte popular nacionalista & style \\
\hline arte popular rural & style \\
\hline arte popular urbano & style \\
\hline arte popular vanguardista & style \\
\hline arte primitivo & associated concept \\
\hline arte típico & associated concept \\
\hline arte tradicional & associated concept \\
\hline arte turístico & associated concept \\
\hline artefacto & associated concept \\
\hline artes aplicadas & associated concept \\
\hline artes decorativas & associated concept \\
\hline artesanía & associated concept \\
\hline artesanía & associated concept \\
\hline artesanía & work type \\
\hline artesanías & work type \\
\hline artesano & associated concept \\
\hline artesano & work type \\
\hline artilugio & associated concept \\
\hline artista popular & associated concept \\
\hline arts and crafts & associated concept \\
\hline Asia & geographic name \\
\hline atzopipa & style \\
\hline Ayacuchano & geographic name \\
\hline azúcar & material \\
\hline Baja California & geographic name \\
\hline Baja California Sur & geographic name \\
\hline Bajío & geographic name \\
\hline
\end{tabular}




\begin{tabular}{|c|c|}
\hline balero & work type \\
\hline barniz & material \\
\hline barnizado & technique \\
\hline barra & work type \\
\hline barro & material \\
\hline barro & work type \\
\hline barro bandera & style \\
\hline barro bruñido & style \\
\hline barro negro & material \\
\hline barro negro & work type \\
\hline barro talavera & style \\
\hline barroco & associated concept \\
\hline barroco & style \\
\hline batea & work type \\
\hline baúl & work type \\
\hline bellas artes & associated concept \\
\hline belleza & associated concept \\
\hline bisutería & work type \\
\hline blusa de telar & style \\
\hline bolsa & work type \\
\hline bolsa de mandado & work type \\
\hline bolsa de mano & work type \\
\hline bordado & material \\
\hline bordado & technique \\
\hline bordado & work type \\
\hline bordado a mano & technique \\
\hline bordado a máquina & technique \\
\hline bordado en punto de cruz & technique \\
\hline brocado & technique \\
\hline broche & material \\
\hline bronce & material \\
\hline bruñido & style \\
\hline bruñido & material \\
\hline bruñido & technique \\
\hline cabello & material \\
\hline cajete & work type \\
\hline calabaza & material \\
\hline calabaza & work type \\
\hline calavera de papel maché & work type \\
\hline camisa & work type \\
\hline Campeche & geographic name \\
\hline canasta & work type \\
\hline candelabro & work type \\
\hline cántaro & work type \\
\hline caña & material \\
\hline caracol & material \\
\hline Caribe & geographic name \\
\hline caricatura & work type \\
\hline
\end{tabular}




\begin{tabular}{|c|c|}
\hline carpintería & work type \\
\hline cartón & material \\
\hline cartonera & technique \\
\hline cartonería & work type \\
\hline cascabel & work type \\
\hline cáscara de calabaza & material \\
\hline caucho & work type \\
\hline cédula de papel & material \\
\hline celulosa & material \\
\hline cemento & material \\
\hline cenicero & work type \\
\hline Centro & geographic name \\
\hline Centro & geographic name \\
\hline Centro de México & geographic name \\
\hline Centro Occidente & geographic name \\
\hline Centroamericano & geographic name \\
\hline ceñidor & work type \\
\hline cepillado & technique \\
\hline cepillado de madera & technique \\
\hline cera & material \\
\hline cera & work type \\
\hline cera de abeja & material \\
\hline cera perdida & technique \\
\hline cerámica & associated concept \\
\hline cerámica & material \\
\hline cerámica & work type \\
\hline cerámica de alta temperatura & style \\
\hline cerámica de alta temperatura & material \\
\hline cerámica de baja temperatura & style \\
\hline cerámica de baja temperatura & material \\
\hline cerámica de fuego & style \\
\hline cerámica de fuego & technique \\
\hline cerámica ornamental & style \\
\hline cerámica utilitaria & style \\
\hline cerería & material \\
\hline cerería & work type \\
\hline cesta & work type \\
\hline cestería & technique \\
\hline cestería & work type \\
\hline cesto & work type \\
\hline cháchara & work type \\
\hline chaquira & material \\
\hline chiapaneco & style \\
\hline Chiapaneco & geographic name \\
\hline Chiapas & geographic name \\
\hline Chihuahua & geographic name \\
\hline Chinanteca & geographic name \\
\hline chomado & technique \\
\hline chospata & work type \\
\hline
\end{tabular}




\begin{tabular}{|c|c|}
\hline cincelado & technique \\
\hline cinta & work type \\
\hline cinturón piteado & work type \\
\hline cirios & work type \\
\hline Ciudad de México & geographic name \\
\hline Coahuila de Zaragoza & geographic name \\
\hline Coatzacoalcos & geographic name \\
\hline cobija & work type \\
\hline cobre & material \\
\hline cobre martillado & work type \\
\hline cobre ornamental & style \\
\hline cobre utilitario & style \\
\hline cocido & technique \\
\hline cocido de barro & technique \\
\hline cocina & work type \\
\hline colección & work type \\
\hline colección cerámica & work type \\
\hline colecciones metálicas & work type \\
\hline coleccionista & associated concept \\
\hline coleccionista & work type \\
\hline colectiva & associated concept \\
\hline colectivo & associated concept \\
\hline Colima & geographic name \\
\hline collage & technique \\
\hline collar & work type \\
\hline color festivo & associated concept \\
\hline color para teñir & material \\
\hline colorante & material \\
\hline colorante animal & material \\
\hline colorante vegetal & material \\
\hline coloreado & technique \\
\hline comal & work type \\
\hline cómic & work type \\
\hline comida & work type \\
\hline comunidad & associated concept \\
\hline concha & material \\
\hline concha & work type \\
\hline concurso & work type \\
\hline conservación & associated concept \\
\hline contenedor & work type \\
\hline copal & work type \\
\hline corrado & technique \\
\hline corral & work type \\
\hline corte & technique \\
\hline corteza & material \\
\hline corteza de árbol & material \\
\hline coscomate & work type \\
\hline costa & style \\
\hline
\end{tabular}




\begin{tabular}{|c|c|}
\hline Costa & geographic name \\
\hline costa chica & style \\
\hline Costa Chica & geographic name \\
\hline Costa Chica de Guerrero & geographic name \\
\hline costa del golfo & style \\
\hline Costa del Golfo & geographic name \\
\hline costumbre & associated concept \\
\hline coyotepec & style \\
\hline creatividad & associated concept \\
\hline cristal & material \\
\hline cubiertos & work type \\
\hline cuchara & work type \\
\hline cuenta & material \\
\hline cuerno & material \\
\hline cuero & material \\
\hline cuero & work type \\
\hline cultura & associated concept \\
\hline cultura de masas & associated concept \\
\hline cultura material & associated concept \\
\hline cultura popular & associated concept \\
\hline curtido & technique \\
\hline curtiduría & technique \\
\hline danza & associated concept \\
\hline danza & work type \\
\hline de la Sierra Gorda & style \\
\hline de Oaxaca & style \\
\hline decoración & associated concept \\
\hline decorado con pintura & technique \\
\hline Del Bajío & geographic name \\
\hline del centro de México & style \\
\hline del Istmo & style \\
\hline derecho de autoría & associated concept \\
\hline deshilado & style \\
\hline deshilado & technique \\
\hline deshilado & work type \\
\hline dibujo & technique \\
\hline diseño & associated concept \\
\hline diseño industrial & associated concept \\
\hline Distrito Federal & geographic name \\
\hline dorado en madera & technique \\
\hline Durango & geographic name \\
\hline ebanistería & associated concept \\
\hline elaborado a mano & associated concept \\
\hline embutido & style \\
\hline enagua & work type \\
\hline enchapado & technique \\
\hline enredo & work type \\
\hline ensamblaje & technique \\
\hline ensamblaje & work type \\
\hline
\end{tabular}




\begin{tabular}{|c|c|}
\hline enseres de casa & work type \\
\hline entintado & material \\
\hline entonchado & technique \\
\hline entorchado & material \\
\hline escamado & technique \\
\hline escapulario & work type \\
\hline esculpido & technique \\
\hline escultura & technique \\
\hline escultura & work type \\
\hline escultura de madera & work type \\
\hline escultura tallada & work type \\
\hline esmaltado & technique \\
\hline espejo & work type \\
\hline espuelas & work type \\
\hline Estado de México & geographic name \\
\hline estambre & material \\
\hline estatuilla & work type \\
\hline estética & associated concept \\
\hline estilo clásico & style \\
\hline estilo étnico & style \\
\hline estilo etnográfico & style \\
\hline estilo huichol & style \\
\hline estilo indígena & style \\
\hline estilo por edad & style \\
\hline estilo por pueblo & style \\
\hline estilo posclásico & style \\
\hline estilo preclásico & style \\
\hline estilo purépecha & style \\
\hline estilo región central & style \\
\hline estilo región del sur & style \\
\hline estilo región huasteca & style \\
\hline estilo región sureste & style \\
\hline estilo regional & style \\
\hline estilo talavera & style \\
\hline estructura madera & material \\
\hline estructura portátil & material \\
\hline exposición & work type \\
\hline expresión cultural & associated concept \\
\hline expresión tradicional & associated concept \\
\hline exvoto & work type \\
\hline faja & work type \\
\hline falda & work type \\
\hline faldilla & work type \\
\hline fibra de lago & material \\
\hline fibra de maguey & material \\
\hline fibra natural & material \\
\hline fibra natural & work type \\
\hline fibra sintética & material \\
\hline
\end{tabular}




\begin{tabular}{|c|c|}
\hline fibra vegetal & material \\
\hline fibra vegetal & work type \\
\hline fibras de origen animal & material \\
\hline fibras sintéticas & material \\
\hline fiesta regional & associated concept \\
\hline figura de cera & work type \\
\hline figura de madera & work type \\
\hline figurilla & work type \\
\hline figurilla de barro & work type \\
\hline filigrana & work type \\
\hline filmación digital analógica & technique \\
\hline flecha & work type \\
\hline florero & work type \\
\hline folclor & geographic name \\
\hline folk & associated concept \\
\hline folk-art & associated concept \\
\hline folklor & associated concept \\
\hline folklore & associated concept \\
\hline folklórico & associated concept \\
\hline fondeado & material \\
\hline fondeado & technique \\
\hline fotomontaje & technique \\
\hline fruta & material \\
\hline frutero & work type \\
\hline fruto & material \\
\hline fundición & technique \\
\hline fundición de metales & technique \\
\hline fundición de vidrio & technique \\
\hline fundido & technique \\
\hline genio individual & associated concept \\
\hline Golfo & geographic name \\
\hline grabado & technique \\
\hline grabado en madera & technique \\
\hline gráfica & work type \\
\hline Gran Nayar & geographic name \\
\hline grana cochinilla & material \\
\hline grupo & geographic name \\
\hline Guadalajara & geographic name \\
\hline guaje & work type \\
\hline Guanajuato & geographic name \\
\hline guayabera & work type \\
\hline Guerrero & geographic name \\
\hline guitarra & work type \\
\hline henequén & material \\
\hline herencia & associated concept \\
\hline herencia cultural & associated concept \\
\hline herramienta & material \\
\hline herramienta & work type \\
\hline herrería & technique \\
\hline
\end{tabular}




\begin{tabular}{|c|c|}
\hline herrería & work type \\
\hline Hidalgo & geographic name \\
\hline hierro & material \\
\hline hierro forjado & work type \\
\hline hilado & technique \\
\hline hilo & material \\
\hline hilo de algodón & material \\
\hline hilos de lana & material \\
\hline hilvanado & technique \\
\hline hipil & style \\
\hline hispano & style \\
\hline Hispanoamericano & geographic name \\
\hline historia & associated concept \\
\hline hoja de palma & material \\
\hline hojalata & material \\
\hline horneado & technique \\
\hline horno & material \\
\hline horno & work type \\
\hline horno de gas & work type \\
\hline horno de madera & work type \\
\hline huanengo & style \\
\hline huarache & work type \\
\hline Huasteca & geographic name \\
\hline Huave & geographic name \\
\hline hueso & material \\
\hline hueso & work type \\
\hline Huichol & geographic name \\
\hline huipil & style \\
\hline huipil & work type \\
\hline identidad & associated concept \\
\hline imagen analógica & material \\
\hline impresión en offset & technique \\
\hline incensario & work type \\
\hline incisión & technique \\
\hline incrustación & technique \\
\hline indígena & associated concept \\
\hline indígena & style \\
\hline indígena & work type \\
\hline indígenas & associated concept \\
\hline indumentaria & associated concept \\
\hline indumentaria & work type \\
\hline industria & associated concept \\
\hline industria manual & associated concept \\
\hline industria típica & associated concept \\
\hline industrias populares & associated concept \\
\hline innovación & associated concept \\
\hline instrumento de cocina & work type \\
\hline instrumento de servicio en mesas & work type \\
\hline
\end{tabular}




\begin{tabular}{|c|c|}
\hline instrumento musical & work type \\
\hline istmeño & style \\
\hline Istmo & geographic name \\
\hline Istmo de Tehuantepec & geographic name \\
\hline ixtle & material \\
\hline Jalisco & geographic name \\
\hline jarra de vidrio & work type \\
\hline jarro & work type \\
\hline jarrón & work type \\
\hline jícara & material \\
\hline jícara & work type \\
\hline jorongo & work type \\
\hline joyería & technique \\
\hline joyería & work type \\
\hline judas & work type \\
\hline juguete & work type \\
\hline juguetería & work type \\
\hline labrado & technique \\
\hline laca & material \\
\hline laca & work type \\
\hline Lacandón & geographic name \\
\hline lajadaria & work type \\
\hline lámina & material \\
\hline laminado & technique \\
\hline lana & material \\
\hline lapidaria & material \\
\hline lapidaria & work type \\
\hline laqueado & style \\
\hline laqueado & material \\
\hline laqueado & technique \\
\hline Latinoamericano & geographic name \\
\hline legado & associated concept \\
\hline leyenda & associated concept \\
\hline lienzo de manta & material \\
\hline Limeño & geographic name \\
\hline listón & material \\
\hline lítica pulida & work type \\
\hline lítica tallada & work type \\
\hline litografía & technique \\
\hline low art & associated concept \\
\hline loza & work type \\
\hline madera & material \\
\hline madera & work type \\
\hline manifestación etnográfica & associated concept \\
\hline mano de obra & associated concept \\
\hline mantel & work type \\
\hline manualidad & associated concept \\
\hline manufactura & associated concept \\
\hline Mapuche & geographic name \\
\hline
\end{tabular}




\begin{tabular}{|c|c|}
\hline máquina de coser & material \\
\hline marginación & associated concept \\
\hline mariposa & material \\
\hline martillado & material \\
\hline martillado & technique \\
\hline máscara & work type \\
\hline materia prima & work type \\
\hline material repujado & technique \\
\hline maya & style \\
\hline Maya & geographic name \\
\hline Mazahua & geographic name \\
\hline mecanizar & associated concept \\
\hline mecapal & work type \\
\hline mercado & associated concept \\
\hline mercado & work type \\
\hline mercancía artesanal & associated concept \\
\hline mesa tallada & work type \\
\hline Mesoamérica & geographic name \\
\hline metal & material \\
\hline metal & work type \\
\hline metalurgia & work type \\
\hline metate & work type \\
\hline Metepec & geographic name \\
\hline mexica & style \\
\hline Mexicano & geographic name \\
\hline México & geographic name \\
\hline michoacán & style \\
\hline Michoacán & geographic name \\
\hline Michoacán de Ocampo & geographic name \\
\hline Michoacano & geographic name \\
\hline migajón & work type \\
\hline mineral & material \\
\hline minerales & material \\
\hline miniatura & associated concept \\
\hline miniatura & work type \\
\hline minoría & associated concept \\
\hline mixe & style \\
\hline Mixe & geographic name \\
\hline Mixteca & geographic name \\
\hline Mixteca Alta & geographic name \\
\hline Mixteca Baja & geographic name \\
\hline modelado & technique \\
\hline modelado en torno & technique \\
\hline molcajete & work type \\
\hline molde & technique \\
\hline moldeado & technique \\
\hline moldeado en barro & technique \\
\hline montaje & technique \\
\hline
\end{tabular}




\begin{tabular}{|c|c|}
\hline montaña & style \\
\hline Morelos & geographic name \\
\hline morral & work type \\
\hline mortero & technique \\
\hline mueble & work type \\
\hline muñeca & work type \\
\hline mural & work type \\
\hline museo & associated concept \\
\hline museo & work type \\
\hline música & work type \\
\hline nácar & work type \\
\hline nacimiento & work type \\
\hline nación & associated concept \\
\hline nahua & style \\
\hline Nahua & geographic name \\
\hline Nayarit & geographic name \\
\hline norte & style \\
\hline Norte & geographic name \\
\hline Norte & geographic name \\
\hline Norteamérica & geographic name \\
\hline novohispano & style \\
\hline Nuevo León & geographic name \\
\hline Oaxaca & geographic name \\
\hline Oaxaqueño & geographic name \\
\hline objeto decorativo & work type \\
\hline objeto utilitario & associated concept \\
\hline objetos de la vida cotidiana & associated concept \\
\hline obsidiana & work type \\
\hline occidente & style \\
\hline Occidente & geographic name \\
\hline Occidente & geographic name \\
\hline Occidente Mexicano & geographic name \\
\hline oficio & associated concept \\
\hline oficio & work type \\
\hline ofrenda & associated concept \\
\hline ofrenda & work type \\
\hline óleo & material \\
\hline óleo & technique \\
\hline olinalá & style \\
\hline Olinalá & geographic name \\
\hline olla & work type \\
\hline olmeca & style \\
\hline orfebrería & associated concept \\
\hline ornamento & associated concept \\
\hline ornamentos de hogar & work type \\
\hline oro & material \\
\hline oro y minerales & material \\
\hline Otomí & geographic name \\
\hline paliacate & work type \\
\hline
\end{tabular}




\begin{tabular}{|c|c|}
\hline palma & material \\
\hline palma & work type \\
\hline pan & material \\
\hline Pápago & geographic name \\
\hline papel & material \\
\hline papel & work type \\
\hline papel amate & work type \\
\hline papel maché & material \\
\hline papel periódico & material \\
\hline papel picado & work type \\
\hline parafina & material \\
\hline pasta & work type \\
\hline pasto & material \\
\hline patrimonio intangible & associated concept \\
\hline patrimonio tangible & associated concept \\
\hline Pátzcuaro & geographic name \\
\hline pegamento & material \\
\hline peineta & work type \\
\hline peletería & technique \\
\hline película & work type \\
\hline penacho & work type \\
\hline Península & geographic name \\
\hline Península & geographic name \\
\hline Peninsular & geographic name \\
\hline perfilado & technique \\
\hline perfilado en oro & style \\
\hline periódico & material \\
\hline petate & work type \\
\hline piedra & material \\
\hline piedra preciosa & material \\
\hline piedra volcánica & material \\
\hline piedra volcánica & work type \\
\hline piel & material \\
\hline piel & work type \\
\hline pieza única & associated concept \\
\hline pigmento & material \\
\hline pigmento animal & material \\
\hline pigmento mineral & material \\
\hline pigmento vegetal & material \\
\hline pintado & technique \\
\hline pintado en frío & technique \\
\hline pintura & material \\
\hline pintura & technique \\
\hline pintura & work type \\
\hline pintura automotiva & material \\
\hline pintura mural & work type \\
\hline pintura natural & material \\
\hline pintura sintética & material \\
\hline
\end{tabular}




\begin{tabular}{|c|c|}
\hline piñata & work type \\
\hline piroxilina & material \\
\hline plagio & associated concept \\
\hline planta & material \\
\hline plástico & material \\
\hline plástico & work type \\
\hline plata & material \\
\hline Platera & geographic name \\
\hline platería & work type \\
\hline plomo & material \\
\hline pluma & material \\
\hline pluma & work type \\
\hline plumaria & material \\
\hline plumaria & technique \\
\hline plumaria & work type \\
\hline poblano & style \\
\hline Poblano & geographic name \\
\hline policromía & technique \\
\hline política pública & associated concept \\
\hline pólvora & material \\
\hline porcelana & material \\
\hline póster & work type \\
\hline postetotémico & work type \\
\hline prehispánico & associated concept \\
\hline prendedor & work type \\
\hline producción & associated concept \\
\hline producción manual & associated concept \\
\hline producción plástica aborigen & associated concept \\
\hline producto & work type \\
\hline Puebla & geographic name \\
\hline pueblo & associated concept \\
\hline pueblo originario & associated concept \\
\hline pulido & technique \\
\hline pulido de piedra & technique \\
\hline Purépecha & geographic name \\
\hline quechquemetl & work type \\
\hline quemado & material \\
\hline Querétaro & geographic name \\
\hline quexquemetl & work type \\
\hline Quintana Roo & geographic name \\
\hline raíz & associated concept \\
\hline raíz & material \\
\hline Rarámuri & geographic name \\
\hline rayado & technique \\
\hline ready made & work type \\
\hline rebozo & work type \\
\hline región & associated concept \\
\hline Región Central & geographic name \\
\hline Región de la Cañada de los Pueblos & geographic name \\
\hline
\end{tabular}




\begin{tabular}{|c|c|}
\hline Región de la Cuenca del Río Lerma & geographic name \\
\hline Región de la Frontera & geographic name \\
\hline Región de la Selva & geographic name \\
\hline Región de Montaña & geographic name \\
\hline Región de Oriente & geographic name \\
\hline Región de Tierra Caliente & geographic name \\
\hline Región del Bajío & geographic name \\
\hline Región del Sur & geographic name \\
\hline Región del Valle & geographic name \\
\hline Región del Valle de Toluca & geographic name \\
\hline Región Geográfica & geographic name \\
\hline Región Geopolítica & geographic name \\
\hline Región Lacustre & geographic name \\
\hline Región Mazahua & geographic name \\
\hline Región Norte & geographic name \\
\hline Región Otomí & geographic name \\
\hline Región Peninsular & geographic name \\
\hline Región Sureste & geographic name \\
\hline reivindicación & associated concept \\
\hline relato & associated concept \\
\hline representación & associated concept \\
\hline repujado & technique \\
\hline resina & material \\
\hline retablo & work type \\
\hline revista & work type \\
\hline Rioplatense & geographic name \\
\hline ritual & associated concept \\
\hline ropa & work type \\
\hline rural & associated concept \\
\hline rural & geographic name \\
\hline saber & work type \\
\hline saber tradicional & associated concept \\
\hline San Luis Potosí & geographic name \\
\hline sarape & work type \\
\hline secado al sol de materiales de barro & technique \\
\hline seda & material \\
\hline seda mariposa & material \\
\hline semilla & material \\
\hline sencillo & style \\
\hline serigrafía & technique \\
\hline sierra & material \\
\hline Sierra Norte de Puebla & geographic name \\
\hline silla & work type \\
\hline silla de mimbre & work type \\
\hline silla de montar & work type \\
\hline silla tallada & work type \\
\hline Sinaloa & geographic name \\
\hline sociedad hegemónica & associated concept \\
\hline
\end{tabular}




\begin{tabular}{|c|c|}
\hline sombrero & work type \\
\hline Sonora & geographic name \\
\hline souvenir & associated concept \\
\hline subalterno & associated concept \\
\hline Sudamérica & geographic name \\
\hline suéter & work type \\
\hline Sur & geographic name \\
\hline Sur de México & geographic name \\
\hline Sureste & geographic name \\
\hline Sureste de México & geographic name \\
\hline Tabasco & geographic name \\
\hline talabartería & technique \\
\hline talabartería & work type \\
\hline talavera & work type \\
\hline talavera de puebla & style \\
\hline talavera poblana & style \\
\hline talla & work type \\
\hline talla de madera & material \\
\hline talla directa & technique \\
\hline talla directa en madera & technique \\
\hline tallado & technique \\
\hline tallado & work type \\
\hline tallado de piedra & technique \\
\hline tallado en madera & technique \\
\hline Tamaulipas & geographic name \\
\hline tapete & work type \\
\hline tapiz & work type \\
\hline Tarasca & geographic name \\
\hline tarasco & style \\
\hline Taxco & geographic name \\
\hline taza & work type \\
\hline técnica & associated concept \\
\hline técnica de producción & work type \\
\hline técnica original & associated concept \\
\hline tecnología & associated concept \\
\hline tejido & material \\
\hline tejido & technique \\
\hline tejido & work type \\
\hline tejido con aguja & technique \\
\hline tejido con gancho & technique \\
\hline tejido de palma & technique \\
\hline tejido de sombreros & technique \\
\hline tejido en crochet & technique \\
\hline tejido en ixtle & work type \\
\hline tejido en telar de cintura & technique \\
\hline tejido en telar de pedales & technique \\
\hline tela & material \\
\hline tela & work type \\
\hline telar & material \\
\hline
\end{tabular}




\begin{tabular}{|c|c|}
\hline telar & technique \\
\hline telar & work type \\
\hline telar de cintura & style \\
\hline telar de cintura & material \\
\hline telar de cintura & technique \\
\hline telar de cintura & work type \\
\hline telar de pedal & material \\
\hline telar de pedales & work type \\
\hline telar horizontal & style \\
\hline telar mecánico & material \\
\hline telar mecánico & technique \\
\hline telar vertical & style \\
\hline teñido & technique \\
\hline teotihuacano & style \\
\hline Tepehuana & geographic name \\
\hline textil & material \\
\hline textil & work type \\
\hline textiles & work type \\
\hline tianguis & work type \\
\hline tibor & work type \\
\hline tierra natural & material \\
\hline tijeras & material \\
\hline tinta & work type \\
\hline tinta industrial & material \\
\hline tinta natural & material \\
\hline tinte con plomo & work type \\
\hline tinte natural & material \\
\hline tinte natural & work type \\
\hline tintura & material \\
\hline títere & work type \\
\hline tlaquepaque & style \\
\hline Tlaquepaque & geographic name \\
\hline Tlaxcala & geographic name \\
\hline tocado & work type \\
\hline Tojolabal & geographic name \\
\hline tol & work type \\
\hline Tonalá & geographic name \\
\hline torito & work type \\
\hline torneado & technique \\
\hline torno & work type \\
\hline totonaca & style \\
\hline Totonaca & geographic name \\
\hline totonaco & style \\
\hline tradición & associated concept \\
\hline tradición & work type \\
\hline trama & work type \\
\hline trenzado & technique \\
\hline Triqui & geographic name \\
\hline
\end{tabular}




\begin{tabular}{|c|c|}
\hline trompo & work type \\
\hline Tzetzal & geographic name \\
\hline Tzintzuntzan & geographic name \\
\hline Tzotzil & geographic name \\
\hline único & associated concept \\
\hline urbano & geographic name \\
\hline urdido & material \\
\hline urdimbre & work type \\
\hline Uruapan & geographic name \\
\hline uso cotidiano & associated concept \\
\hline uso de horno & technique \\
\hline utensilio & work type \\
\hline vaciado & technique \\
\hline vajilla & work type \\
\hline valle & style \\
\hline Valle de México & geographic name \\
\hline Valles & geographic name \\
\hline Valles Centrales & geographic name \\
\hline Valles de Oaxaca & geographic name \\
\hline valor & associated concept \\
\hline valor artístico & geographic name \\
\hline vanguardia latinoamericana & associated concept \\
\hline vasija & work type \\
\hline vasijas & work type \\
\hline vaso & work type \\
\hline velas de cera & work type \\
\hline Veracruz & geographic name \\
\hline Veracruz de Ignacio de la Llave & geographic name \\
\hline vernáculo & associated concept \\
\hline vestimenta & work type \\
\hline vidriado & style \\
\hline vidriado & technique \\
\hline vidrio & material \\
\hline vidrio & work type \\
\hline vidrio soplado & material \\
\hline vidrio soplado & technique \\
\hline xicalpextle & work type \\
\hline xilografía & work type \\
\hline yalalteca & style \\
\hline Yucatán & geographic name \\
\hline yute & material \\
\hline Zacatecas & geographic name \\
\hline zarape & work type \\
\hline zempasúchil & material \\
\hline Zona Lacustre & geographic name \\
\hline zona maya & style \\
\hline Zona Maya & geographic name \\
\hline Zoque & geographic name \\
\hline
\end{tabular}

